\title{
Pengaruh Altman Z-Score Terhadap Realized Return Perusahaan Terbuka di Indonesia
}

\author{
Andre Reinaldi, Devia Alvionita, Vebby Tjakranegara, \\ Yane Chande ra, Rathria Arrina Rachman *) \\ Program Studi Keuangan, Sekolah Bisnis dan Ekonomi Universitas Prasetiya Mulya \\ BSD City Kavling Edutown I.1 , Jl. BSD Raya Utama, BSD City, Tangerang 15339
}

Keywords: Altman Z-Score, financial distress, stock market return, Indonesia

\section{Kata Kunci:}

Altman Z-Score, imbal balik saham, kesulitan keuangan, Indonesia.

* Corresponding author: rathria.rachman@pmbs.ac.id

\begin{abstract}
This study aims to examine whether there is a relationship between Altman Z-Score (financial distress predictor) and realized return on company's stock, and how much the influence of Altman Z-Score on the realized stock returns. One way to find out the company's financial condition is using the Altman Z"-score Modification method (Altman, 2002) which is applied in this research. The sample in this study is public companies that are listed on the Indonesia Stock Exchange during the period 2013-2017. This study finds that the company's Altman Z-Score has a positive effect on the realized stock market returns, which means that when a company approaches the condition of is getting closer to financial distress, the realized return on its shares is lower. This study is in line with previous research by Campbell et al. (2008), Dichev (1998), and Griffin and Lemmon (2002). This research is useful for investors for determining their investment strategy and for companies' management for monitoring and maintaining the company's goodfinancial condition.
\end{abstract}

\section{Sari Pati}

Penelitian ini bertujuan untuk menguji apakah terdapat hubungan antara Altman Z-Score (prediktor kesulitan keuangan atau financial distress) dan imbal balik saham (realized stock return), serta seberapa besar pengaruh Altman Z-Score terhadap imbal balik saham perusahaan. Salah satu cara untuk mengetahui kondisi kesehatan keuangan suatu perusahaan adalah dengan menggunakan metode Altman Z"-score Modifikasi (Altman, 2002) yang digunakan sebagai pengukuran dalam penelitian ini. Sampel pada penelitian ini adalah perusahaan terbuka yang terdaftar di Bursa Efek Indonesia pada tahun 2013-2017. Penelitian ini menemukan hasil bahwa Altman ZScore perusahaan berpengaruh positif terhadap imbal balik saham yang berarti ketika suatu perusahaan semakin mendekati kondisi kesulitan keuangan, maka imbal balik saham yang didapatkan akan semakin rendah. Penelitian ini sejalan dengan penelitian terdahulu oleh Campbell et al. (2008), Dichev (1998), dan Griffin dan Lemmon (2002). Penelitian ini berguna bagi investor untuk menentukan strategi investasinya dan juga bagi manajemen perusahaan untuk memantau dan mempertahankan kondisi keuangan perusahaan yang baik. 


\section{Pendahuluan}

Di Indonesia terdapat sejumlah kasus perusahaan berada dalam kondisi kesulitan keuangan (financial distress) yang berujung kebangkrutan. Pada tahun 2017 ada tiga perusahaan di-delisting dari Bursa Efek Indonesia (BEI), yaitu PT Berau Coal Energy Tbk (BRAU), PT Citra Maharlika Nusantara Corpora Tbk (CPGT), dan PT Dwi Aneka Jaya Kemasindo Tbk (DAJK) karena perusahaan tersebut dinyatakan pailit oleh pengadilan. BRAU, CPGT, dan DAJK mengalami pailit dikarenakan perusahaan berada dalam kondisi kesulitan keuangan (financial distress) dan menyebabkan perusahaan gagal dalam memenuhi kewajibannya kepada para kreditor, sehingga perusahaan dinyatakan pailit oleh pengadilan dan seluruh asetnya disita. Sebelum perusahaan dinyatakan pailit, mereka mengalami kondisi kesulitan keuangan (financial distress) yang dapat diukur menggunakan indikator Altman Z-score. Sebagai contoh, PT Berau Coal Energy Tbk (BRAU) dari tahun 2012 sampai dengan 2014 nilai Z-score perusahaannya berada di bawah standar model Altman Z-score. Oleh karena itu, dapat dikatakan bahwa perusahaan termasuk dalam kategori financial distress sebelum menga lami kebangkrutan (Setyawan et al., 2018).

Financial distress merupakan keadaan disaat perusahaan tidak mampu untuk menye lesaikan tanggung jawab keuangannya tepat waktu dan bisa mengakibatkan suatu perusahaan dinyatakan bangkrut (Darsono dan Ashari, 2005). Oleh karena itu, financial distress merupakan sebuah tahapan sebelum terjadinya kebangkrutan sehingga manajemen perusahaan harus lebih cermat dalam mengatasi permasalahan dan pengambilan keputusan perusahaan. Beberapa hal yang dapat menyebabkan financial distress antara lain adalah arus kas, utang, krisis atau kesulitan ekonomi, penurunan kondisi industri perusahaan, manajemen yang buruk, dan lain-lain (Low et al., 2001; Fisher, 1959; Wruck, 1990; Whitaker, 1999).

Pendanaan dibutuhkan untuk kegiatan operasional perusahaan, salah satunya untuk berekspansi. Utang merupakan salah satu alternatif pendanaan dan merupakan salah satu media pendanaan yang paling umum digunakan oleh perusahaan. Meskipun demikian, pendanaan melalui hutang juga diikuti dengan kewajiban dalam bentuk membayar bunga dan pokoknya saat jatuh tempo. 
Dengan demikian, peningkatan jumlah utang akan meningkatkan pula probabilitas sebuah perusahaan mengalami financial distress dan kebangkrutan (Fisher, 1959).

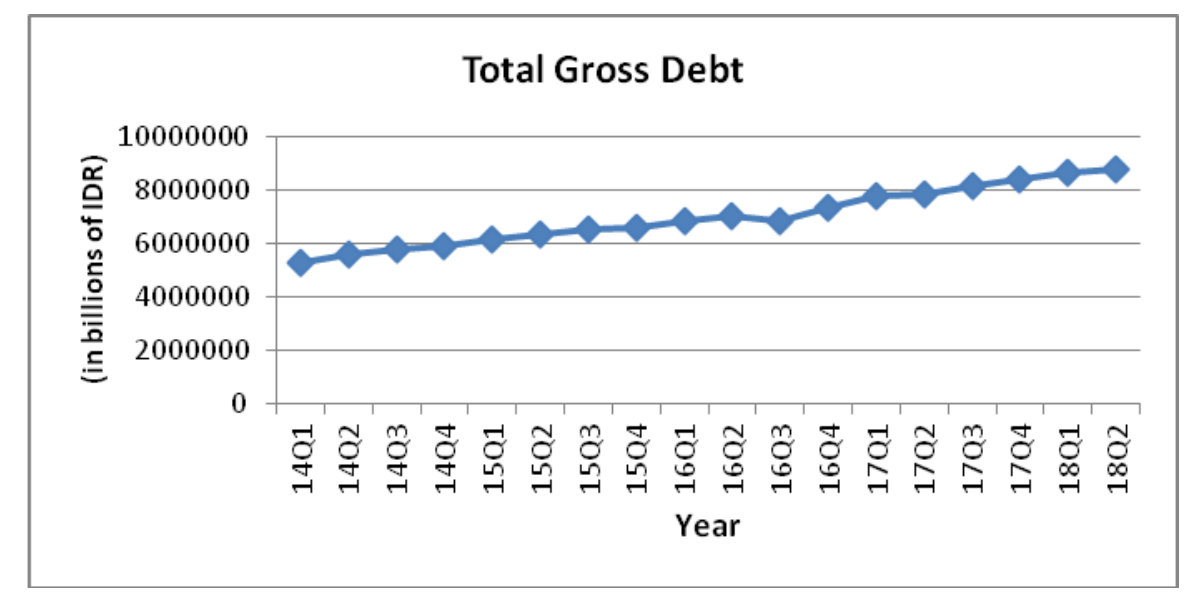

\section{Gambar 1. Grafik Total Gross Debt Pe rusahaan di Indonesia 2012 - 2017}

(Sumber: Data Statistik Bank Indonesia, sumber data diolah)

Melihat hasil statistik dari Bank Indonesia tahun 2017, dalam lima tahun terakhir jumlah utang kotor (gross debt) yang dimiliki oleh perusahaan-perusahaan terbuka di Indonesia memiliki tren yang terus meningkat dari sebesar Rp5.288.271 miliar pada kuartal pertama tahun 2014 menjadi Rp8.754.240 miliar pada kuartal terakhir tahun 2018 atau naik sebesar CAGR 65,54\% selama lima tahun. Peningkatan utang ini menandakan bahwa potensi perusahaan-perusahaan di Indonesia mengalami financial distress juga meningkat. Menurut Fisher (1959), perusahaan mengalami potensi kebangkrutan ketika utang perusahaan semakin bertambah sehingga pendapatan perusahaan sudah tidak lagi mampu untuk memenuhi pembayaran utang tersebut.

Dalam memprediksi kesehatan keuangan suatu perusahaan terdapat beberapa metode yang dapat digunakan seperti metode Altman Z-Score, Springate, dan Zmijewski (Sinarti dan Sembiring, 2015). Menurut Hadi dan Anggraeni (2008), metode Altman Z-Score dapat memprediksi delisting lebih baik daripada metode Springate dan Zmijewski. Nilai signifikansi F dari metode Altman ZScore sebesar 0,03004 dan berada pada level signifikansi moderat. Sedangkan metode Springate memiliki nilai signifikansi $\mathrm{F}$ lebih rendah 0,0033 dari metode Altman Z-Score, sehingga dapat dikatakan metode Altman Z-Score lebih baik dalam memprediksi delisting daripada metode 
Springate. Sedangkan metode Zmijewski dikatakan kurang tepat untuk digunakan sebagai prediktor delisting karena nilai signifikansi F-nya tidak menunjukkan signifikansi (Hadi dan Anggraeni, 2008). Hal ini sesuai dengan penelitian Sinarti dan Sembiring (2015) yang mengatakan tidak adanya perbedaan yang signifikan antara metode Altman Z-Score dan Springate dalam penggunaannya untuk memprediksi kebangkrutan, tetapi ada perbedaan cukup signifikan dalam pendekatan menggunakan metode Zmijewski.

Metode Altman Z-Score pertama kali dikemukakan oleh Edward I. Altman (1968) dengan cara menggunakan Multiple Discriminant Analysis (MDA) atau analisis diskriminan berganda dengan lima rasio keuangan, yaitu working capital to total assets, retained earnings to total assets, earnings before interest and taxes to total assets, market value of equity to book value of total debt, dan sales to total assets. Analisis diskriminan berganda merupakan teknik statistik yang mengidentifikasi beberapa rasio keuangan yang dianggap paling berpengaruh dalam pembentukan nilai dari suatu peristiwa dan kemudian mengembangkannya menjadi model untuk membuatnya lebih mudah untuk menarik kesimpulan dari suatu peristiwa (Husein dan Pambekti, 2014). Metode Altman Z-Score ini terus diperbaharui dan terus dikembangkan. Dengan demikian, model prediksinya menjadi leb ih fleksibel dan dapat mencakup banyak sektor perusahaan (Husein dan Pambekti, 2014). Altman (1968) menggunakan sampel sebanyak 33 perusahaan yang mengalami kebangkrutan dan 33 perusahaan yang tidak mengalami kebangkrutan dan mendapatkan hasil ketepatan prediksi sebesar $95 \%$ untuk data satu tahun sebelum kebangkrutan dan ketepatan prediksi $72 \%$ untuk data dua tahun sebelum kebangkrutan.

Metode Springate (S-Score) dikembangkan pertama kali oleh Gordon L.V. Springate pada tahun 1978 menggunakan MDA dan pada dasarnya merupakan revolusi dari metode Altman Z-Score (Hadi dan Anggraeni, 2008; Fatmawati, 2012; dan Sinarti dan Sembiring, 2015). Dalam memutuskan rasio yang dapat digunakan untuk memprediksi kebangkrutan, Springate memakai MDA untuk memilih empat dari 19 rasio keuangan sehingga didapatkan rasio yaitu working capital to total assets, earnings before interest and taxes to total assets, profit before tax to current liabilities, dan sales to 
total assets). Penelitian ini menggunakan 40 perusahaan dan mendapat ketepatan prediksi sebesar 92,5\% (Springate, 1978).

Metode Zmijewski (X-Score) pertama kali dikemukakan oleh Zmijewski pada tahun 1984. Metode ini memerlukan analisis rasio yang mengukur kinerja, leverage, dan likuiditas suatu perusahaan pada model prediksinya. Zmijewski menggunakan sampel 40 perusahaan yang sudah tidak beroperasi atau mengalami kebangkrutan dan 800 perusahaan yang masih beroperasi pada saat itu. Kriteria penilaian model Zmijewski adalah semakin besar nilai X-Score, berpotensi lebih besar perusahaan tersebut mengalami bangkrut (Zmijewski, 1984).

Berdasarkan sejumlah penelitian terdahulu, metode Altman Z-Score merupakan salah satu indikator yang paling baik dalam memprediksi kondisi keuangan perusahaan dikarenakan metode Altman Z-Score mampu meminimalisir error dalam proses klasifikasi, seperti salah menempatkan klasifikasi perusahaan (Type I Error) (Gunathilaka, 2014). Type I error adalah adanya error dikarenakan kesalahan klasifikasi atau "false positive". Metode Altman Z-score ini, tidak melakukan kesalahan dalam pengklasifikasian seperti misalnya menggolongkan perusahaan yang sedang dalam keadaan distress ke dalam kategori perusahaan yang dalam kondisi sehat. Metode Altman Z-Score juga memiliki tingkat keakuratan yang sangat tinggi yaitu sebesar $95 \%$, setiap perusahaan yang sehat dan yang bangkrut berhasil digolongkan ke dalam kelompoknya yang benar (Altman, 1968). Selain itu, metode Altman Z-Score berfokus kepada seluruh aset yang dimiliki perusahaan (Patunrui dan Yati, 2017), dan memiliki rasio-rasio yang secara serentak memiliki pengaruh terhadap prediksi kebangkrutan. Rasio-rasio yang digunakan adalah rasio untuk menghitung tingkat likuiditas perusahaan, mencerminkan kemampuan perusahaan dalam memperoleh laba, dan yang terakhir kemampuan perusahaan untuk menjamin utang-utangnya dengan modal sendiri. Secara keseluruhan rasio yang digunakan dalam metode Altman Z-Score untuk memprediksi kebangkrutan memiliki hubungan yang saling mempengaruhi dari besar kecilnya modal kerja yang dimiliki perusahaan. Jika modal kerja yang dimiliki besar menandakan bahwa perusahaan bekerja secara produktif dan mampu memperoleh laba usaha yang besar. Peningkatan pada laba usaha ini akan menarik perhatian investor 
untuk menanamkan modalnya dan akan terjadi penambahan pada laba ditahan perusahaan. Begitu juga sebaliknya jika laba usaha yang dimiliki kecil maka kemungkinan perusahaan akan mengalami kebangkrutan menjadi lebih besar (Widiyawati et al., 2015).

Terdapat beberapa penelitian yang te lah dilakukan di luar Indonesia terkait metode Altman ZScore. Pada penelitian di Italia ditemukan bahwa metode Altman Z-Score adalah metode yang memiliki keakuratan dalam menggambarkan kondisi keuangan suatu negara dimana zona financial distress dalam metode Altman Z-Score Modifikasi sesuai dengan konteks di Italia (Altman et al., 2015). Berdasarkan penelitian yang telah dilakukan di Malaysia, tingkat ketepatan metode Altman ZScore dalam memprediksi financial distress cukup besar yaitu sebesar 76,7\% (Thai et al., 2014). Metode Altman Z-Score juga mempunyai keempat rasio yang seimbang walaupun rasio MVE/BVD memberikan kontribusi yang kecil dalam model persamaan (Altman et al., 2014).

Terdapat beberapa penelitian terdahulu yang kontra terhadap metode Altman Z-Score dikarenakan metode Altman Z-Score lebih menekankan terhadap ukuran profitabilitas perusahaan yang bersangkutan (Gunawan et al., 2017). Metode Altman Z-Score tidak menggunakan rasio EBT/CL (Earning Before Taxes/Current Liabilities) karena rasio ini dianggap lebih menggambarkan kondisi perusahaan melalui tingkat laba, biaya operasi, dan pembayaran utang (Meiliawati dan Isharijadi, 2016). Menurut Grice dan Ingram (2001), perlu adanya penyesuaian terhadap koefisiennya karena koefisiennya tidak stabil.

Penelitian ini dilakukan dengan metode Altman Z"-Score Modifikasi sebagai prediktor financial distress suatu perusahaan, metode ini dimodifikasi secara khusus untuk dapat digunakan pada perusahaan non-manufaktur maupun perusahaan manufaktur (Altman et al., 2014) dan cocok untuk negara emerging markets (Altman, 2002), sehingga lebih sesuai dengan kondisi di Indonesia. Selain itu, metode Altman Z-Score sampai saat ini masih banyak dipakai oleh para peneliti, praktisi, dan akademisi dibandingkan model prediksi lainnya (Hadi dan Anggraeni, 2008 dan Fatmawati, 2012). Metode ini menggunakan empat rasio keuangan untuk memprediksi kebangkrutan perusahaan, yaitu working capital to total assets, retained earnings to total assets, earnings before interest and 
taxes to total assets, dan market value of equity to book value of total debt. Berdasarkan metode ini, kesehatan keuangan perusahaan dapat digolongkan ke dalam tiga kategori, yaitu sehat (zona aman), rawan (zona abu-abu), dan sedang dalam financial distress (zona financial distress).

Penelitian mengenai kondisi kesehatan keuangan suatu perusahaan merupakan hal yang sangat penting khususnya bagi calon investor yang akan berinvestasi dengan jangka panjang. Investor dalam kegiatannya melakukan investasi bertujuan untuk mendapatkan realized stock return semaksimal mungkin dengan profil risikonya masing-masing. Imbal hasil dapat berupa capital gain yang diartikan sebagai perbedaan harga saham pada saat pembelian dengan harga saham pada saat penjualan (Suharli, 2005). Kondisi keuangan perusahaan yang buruk (mengalami financial distress) akan mempengaruhi realized stock return yang akan didapatkan oleh investor dimana perusahaan yang sedang financial distress dapat berujung pada kepailitan dan dapat membuat kerugian pada investasi yang dilakukan (Purnomo, 2014). Oleh karena itu, penting bagi investor maupun calon investor untuk mampu menghitung potensi realized stock return yang dapat didapatkan dari kegiatan investasinya.

Berdasarkan teori capital asset pricing model (CAPM), semakin tinggi risiko yang dimiliki pada suatu investasi maka expected return dari investasi tersebut akan meningkat. Menurut Chava et al. (2009), semakin besar leverage akan menyebabkan kemungkinan perusahaan tersebut mengalami financial distress akan semakin besar, sehingga sesuai dengan teori CAPM dimana risiko (beta leverage) perusahaan tersebut meningkat dan menyebabkan expected return kedepannya meningkat. Hal ini akan menyebabkan harga saham perusahaan menurun karena discount rate investor cenderung meningkat ketika mengetahui perusahaan dalam kondisi financial distress. Hal ini juga akan berujung pada menurunnya realized stock return pada tahun ini (Chava et al., 2009).

Penelitian ini bertujuan untuk mengetahui hubungan antara Altman Z-Score dan realized stock return, serta seberapa besar pengaruh Altman Z-Score terhadap realized stock return. Penelitian ini dapat bermanfaat sebagai bahan tambahan dalam pengembangan metode Altman Z"-Score Modifikasi, analisis financial distress, dan realized stock return ataupun penelitian mengenai topik 
yang berkorelasi dengan penelitian ini. Penelitian ini memiliki keunggulan dibandingkan dengan penelitian terdahulu yang sejenis khususnya di Indonesia, dikarenakan penelitian ini tidak hanya berfokus pada satu sektor tertentu (Widiyawati et al., 2015; Patunrui dan Yati, 2017; Meiliawati dan Isharijadi, 2016; dan Adnan dan Arisudhana, 2012), tetapi melainkan peneliti menggunakan seluruh sektor non-keuangan. Selain itu juga dapat dipelajari untuk tambahan pengetahuan dalam bidang pendidikan khususnya di Indonesia. Selain itu penelitian ini juga dapat bermanfaat untuk menjadi salah satu bahan pendukung penelitian selanjutnya, menambah referensi di bidang prediksi financial distress dan realized stock return, membantu internal perusahaan agar dapat terus mengetahui, memantau, dan mempertahankan kondisi keuangan perusahaan, serta membantu investor dan calon investor dalam memilih perusahaan yang tepat untuk investasi. Berdasarkan latar belakang di atas, maka pertanyaan penelitian ini adalah "Apakah Altman Z-Score berpengaruh terhadap realized stock return perusahaan?". Studi ini meneliti sebatas perusahaan-perusahaan terbuka sektor non-keuangan yang terdaftar di Bursa Efek Indonesia periode tahun 2013-2017.

\section{Telaah Literatur dan Pengembangan Hipotes is}

\section{Teori Capital Asset Pricing Model (CAPM)}

Semakin tinggi risiko suatu investasi maka nilai beta dari investasi tersebut juga akan semakin tinggi, sehingga dapat dikatakan bahwa expected return dari suatu aset investasi akan memiliki nilai yang sejalan dengan risiko investasinya (Sharpe, 1964). Semakin berisiko aset tersebut maka expected return dari aset tersebut akan semakin besar (high risk, high return). Salah satu landasan dalam teori keuangan adalah hubungan yang positif antara risiko dan imbal balik. Hubungan positif yang dimaksud berasal dari penalaran risk-averse dikarenakan para investor tidak akan mendukung risiko yang lebih tinggi dengan tingkat pengembalian yang sama, mereka hanya akan menerima risiko yang lebih tinggi jika mereka mendapatkan pengembalian yang lebih tinggi (Nickel dan Rodriguez, 2002). Seorang investor dapat memperoleh tingkat pengembalian expected rate of return yang lebih tinggi terhadap kepemilikannya hanya dengan menimbulkan risiko tambahan (Sharpe, 1964). Tetapi dalam 
penelitian ini, ketika suatu perusahaan semakin mengalami financial distress maka realized stock return yang didapatkan oleh para investor semakin rendah. Hal ini dikarenakan ketika suatu perusahaan mengalami financial distress (high risk) maka expected return yang didapatkan akan semakin tinggi (high return) sesuai dengan teori CAPM. Dengan meningkatnya expected return yang dihasilkan maka akan meningkatkan discount rate yang menyebabkan realized stock return saat ini akan mengalami penurunan. Menurut Fama dan French (1988), hal ini disebabkan karena adanya discount-rate effect yang antara lain merupakan penyesuaian terhadap harga saat ini yang disebabkan oleh "shock" yang terjadi pada discount rate dan expected return, sehingga menyebabkan harga saat ini (realized stock return) akan mengalami penurunan karena adanya penyeimbangan terhadap penurunan harga pada saat ini.

\section{Teori Realized Return}

Realized stock return (realized return) merupakan keuntungan yang didapatkan oleh investor dan dapat dinikmati dari hasil investasi yang dilakukan (Ang, 1997). Julini et al. (2015) menyatakan realized stock return merupakan selisih dari modal yang diinvestasikan dengan jumlah yang diterima. Realized return tidak menjamin pengembalian tetap dan tunduk pada risiko pasar. Realized return dapat bernilai positif maupun negatif dan sifatnya tidak homogen yang dapat beragam dari investorke-investor tergantung pada jumlah risiko yang disiapkan dan kualitas analisis pasar sahamnya.

Realized return bisa didapatkan melalui capital gain atau capital loss yang merupakan selisih dari harga saham saat beli dengan harga saham saat dijual saat melakukan investasi. Jika harga saham saat jual lebih tinggi dibandingkan harga saham saat beli maka investor mendapatkan keuntungan atau capital gain. Sedangkan jika harga saham saat jual lebih rendah dibandingkan dengan harga saham saat beli, hal ini menandakan bahwa investor mengalami kerugian atau capital loss. Realized return pada penelitian ini menggunakan capital gain, mengacu pada penelitian yang dilakukan oleh Dichev (1998).

Teori Financial Distress dan Metode Altman Z-Score 
Financial distress secara umum merupakan kondisi perusahaan yang sedang berada dalam kondisi kesulitan keuangan dimana perusahaan tidak dapat memenuhi kewajibannya yang dapat mengakibatkan kebangkrutan (Malik et al., 2013; Darsono dan Ashari, 2005). Menurut Jensen dan Meckling (1976), sebuah perusahaan telah masuk ke dalam tahap awal kondisi financial distress ketika pada tahun pertama perusahaan tersebut memiliki perputaran arus kas lebih kecil dibandingkan utang jangka panjang yang jatuh tempo saat itu. Suatu perusahaan juga dinyatakan dalam keadaan financial distress tidak hanya ketika dinyatakan bangkrut, tetapi ketika kondisi perusahaan tersebut memenuhi dua kondisi yaitu: (1) earnings before interest and taxes depreciation and amortization (EBITDA) berada dibawah beban keuangan selama dua tahun berturut-turut yang menuntun perusahaan pada kondisi tidak mampu lagi untuk menghasilkan dana dari kegiatan operasional perusahaan untuk memenuhi financial obligation-nya; dan (2) market value perusahaan mengalami penurunan selama dua tahun berturut-turut (perusahaan yang telah mengalami defisit dari kegiatan operasionalnya akan mendapat penilaian negatif dari pasar dan stakeholders-nya dan menyebabkan perusahaan akan menerima dampak negatif dari financial distress sampai keadaan ekonominya pulih kembali) (Pindado et al., 2008).

Model perhitungan yang dapat digunakan untuk mengukur financial distress adalah metode Altman Z-Score. Altman (2002) menyatakan bahwa metode Altman Z-Score ini sudah diperbaharui sebanyak dua kali. Yang pertama adalah Altman Z-Score (untuk perusahaan manufaktur yang telah go public), kemudian dilakukan pembaharuan menjadi Altman Z'-Score Revisi (untuk perusahaan manufaktur pribadi yang belum go public), dan pembaharuan yang terakhir menjadi Altman Z' -Score Modifikasi (untuk perusahaan non-manufaktur dan emerging markets). Metode Altman Z-Score terdiri dari lima variabel yang menghasilkan sebuah fungsi diskriminan. Kelima variabel tersebut adalah:

$\mathrm{X}_{1}$ : Working Capital/Total Assets (WC/TA)

$\mathrm{X}_{2}$ : Retained Earnings/Total Assets (RE/TA)

$\mathrm{X}_{3}$ : Earnings Before Interest and Taxes/Total Assets (EBIT/TA) 
$\mathrm{X}_{4}$ : Market Value of Equity/Book Value of Total Debt (MVE/BVD)

$\mathrm{X}_{5}$ : Sales/Total Assets (S/TA)

Penelitian ini menggunakan metode Altman Z-Score Modifikasi dikarenakan lebih cocok untuk Indones ia, yaitu negara dengan emerging market. Seperti yang telah ditulis oleh Altman (2002), fungsi diskriminan dari metode Altman Z"-Score Modifikasi yaitu,

$Z ”=6,56 X_{1}+3,26 X_{2}+6,72 X_{3}+1,05 X_{4}$

Z” : Bankruptcy Index

Dalam metode Altman Z''-Score Modifikasi, Edward I. Altman mengeluarkan variabel $\mathrm{X}_{5}$ yaitu sales per total assets dari fungsi diskriminan. Hal ini dikarenakan setelah melakukan pengukuran terhadap semua variabel sebelum kebangkrutan terjadi dan menghasilkan F-statistics, yang menggambarkan variabel $\mathrm{X}_{1}$ sampai variabel $\mathrm{X}_{4}$ signifikan terhadap potensi kebangkrutan perusahaan non-manufaktur pada level 0,001 . Sedangkan variabel $\mathrm{X}_{5}$ tidak menunjukan perbedaan yang signifikan dan pada test univariate statistical significance test basis, variabel ini tidak muncul sama sekali. Tetapi jika digabungkan dengan variabel-variabel lain, kontribusi rasio sales per total assets cukup besar dikarenakan hubungannya dengan variabel la in da lam model.

Pengukuran tingkat kebangkrutan yang dimiliki oleh perusahaan dapat dilihat dari nilai Z' Score yang dihasilkan. Jika hasil dari nilai Z"'-Score lebih besar dari 2,9, maka perusahaan tergolong dalam zona aman. Jika hasil dari nilai Z',-Score diantara 1,23 dan 2,9, maka perusahaan tergolong dalam zona abu-abu. Jika hasilnya lebih kecil dari 1,23, maka perusahaan tergolong dalam zona financial distress.

Variabel Altman Z-Score ini berpengaruh negatif terhadap financial distress. Dimana semakin kecil nilai Altman Z-Score suatu perusahaan, maka perusahaan tersebut semakin mendekati kondisi financial distress.

\section{Pengembangan Hipotesis}

Secara umum, penelitian terdahulu yang dilakukan di berbagai negara mengatakan bahwa kondisi Altman Z-Score dapat mempengaruhi realized stock return (Campbell et al., 2008; Dichev, 
1998; Griffin dan Lemmon, 2002; dan Chava et al., 2009). Mengacu pada Altman (2002) serta Ardian dan Khoiruddin (2014), berikut merupakan kerangka pemikiran dalam penelitian ini:

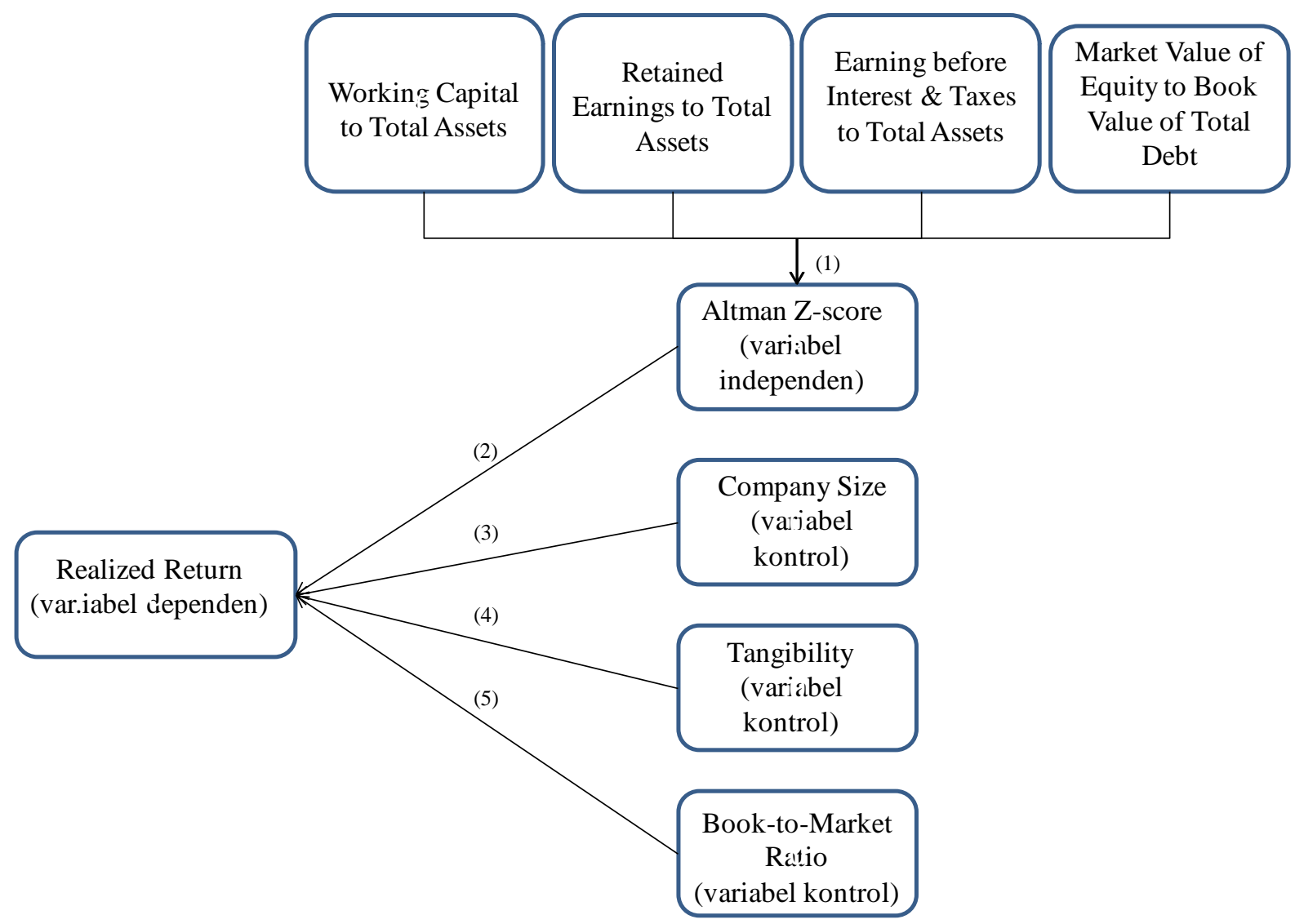

\section{Gambar 2. Ke rangka Pemikiran}

Panah nomor (1) menunjukkan bahwa penelitian ini menggunakan metode Altman Z"-Score Modifikasi (Altman, 2002) sebagai prediktor financial distress. Panah nomor (2) menunjukkan Altman Z-Score sebagai variabel independen diperkirakan akan berpengaruh positif terhadap realized stock return sebagai variabel dependennya. Panah nomor (3) menunjukkan company size sebagai variabel kontrol diperkirakan akan berpengaruh negatif terhadap realized stock return sebagai variabel dependennya. Panah nomor (4) menunjukkan tangibility sebagai variabel kontrol diperkirakan akan berpengaruh positif terhadap realized stock return sebagai variabel dependennya. Panah nomor (5) menunjukkan rasio book-to-market sebagai variabel kontrol diperkirakan akan berpengaruh negatif terhadap realized stock return sebagai variabel dependennya. 
Berdasarkan penelitian terdahulu dan data yang telah ditemukan, maka hipotesis dari penelitian ini adalah sebagai berikut:

$\mathrm{H}_{0}$ : Altman Z-Score perusahaan tidak berpengaruh positif terhadap realized stock return.

$\mathrm{H}_{1}$ : Altman Z-Score perusahaan berpengaruh positif terhadap realized stock return.

Dasar keputusan pada penelitian ini adalah terima $\mathrm{H}_{0}$ jika nilai Altman Z-Score suatu perusahaan tidak memiliki pengaruh terhadap realized stock return.

\section{Metode Penelitian}

\section{Data dan Sampel}

Populasi dalam penelitian ini adalah perusahaan terbuka yang terdaftar di Bursa Efek Indonesia periode tahun 2013-2017. Pengambilan sampel dalam penelitian ini menggunakan teknik purposive sampling. Kriteria yang ditetapkan oleh peneliti adalah (1) perusahaan yang terdaftar di Bursa Efek Indonesia selama tahun 2013-2017, (2) perusahaan sektor non-keuangan karena perusahaan sektor keuangan memiliki struktur laporan keuangan yang berbeda dengan sektor lainnya (Opler dan Titman, 1994), (3) perusahaan yang memiliki data-data laporan keuangan lengkap dan dipublikasikan, dan (4) perusahaan memiliki data yang lengkap terkait dengan variabel independen dan dependen yang digunakan dari tahun 2013-2017.

Data-data pada penelitian ini bersumber dari Bloomberg dan laporan keuangan perusahaan. Dalam penelitian ini data yang digunakan merupakan jenis data panel. Pada penelitian ini, jumlah “individu” yang digunakan ada 366 (tiga ratus enam puluh enam) perusahaan dan periode waktu yang digunakan adalah lima tahun dengan total data sebanyak 1.830 (seribu delapan ratus tiga puluh) data.

\section{Operasionalisasi Variabel}

Variabel pene litian ini terdiri dari Altman Z-Score, realized stock return, company size, rasio book-to-market, dan tangibility. Variabel independen pada penelitian ini adalah Altman Z-Score. Variabel dependen pada penelitian ini adalah realized stock return. Variabel kontrol pada penelitian 
ini adalah company size, rasio book-to-market, dan tangibility. Adapun operasionalisasi variabel penelitian ini dapat dideskripsikan pada tabel 3.1.

Tabel 1. Ope rasionalisasi Variabel

\begin{tabular}{|c|c|c|c|c|c|}
\hline No & Variabel & $\begin{array}{c}\text { Jenis } \\
\text { Variabel }\end{array}$ & Definisi & Indikator & Rumus \\
\hline 1 & $\begin{array}{l}\text { Altman Z- } \\
\text { Score }\end{array}$ & Independen & $\begin{array}{l}\text { Perhitungan yang } \\
\text { menunjukkan kondisi financial } \\
\text { distress atau tekanan keuangan } \\
\text { atas entitas tersebut }\end{array}$ & DISTRESS & $\begin{array}{l}Z "=6,56 X_{1}+3,26 X_{2}+ \\
6,72 X_{3}+1,05 X_{4}\end{array}$ \\
\hline 2 & $\begin{array}{l}\text { Realized } \\
\text { return }\end{array}$ & Dependen & $\begin{array}{l}\text { Imbal balik yang didapatkan } \\
\text { dari selisih harga saham akh ir } \\
\text { tahun t dengan akhir tahun t-1 }\end{array}$ & SMR & $\begin{array}{l}\text { Realized return }=\frac{P_{t}-P_{t-1}}{P_{t-1}} \\
\frac{P_{t}-P_{t-1}}{P_{t-1}}\end{array}$ \\
\hline 3 & $\begin{array}{l}\text { Company } \\
\text { Size }\end{array}$ & Kontrol & $\begin{array}{l}\text { Ukuran perusahaan (company } \\
\text { size) merupakan } \\
\text { menggambarkan besar } \\
\text { kecilnya suatu perusahaan } \\
\text { yang ditunjukan pada market } \\
\text { value of equity. }\end{array}$ & $S I Z E$ & $\begin{array}{l}\text { Company size }=\log (\text { Market } \\
\text { Value of Equity })= \\
\log (\mathrm{MVE})\end{array}$ \\
\hline 4 & $\begin{array}{l}\text { Book-to- } \\
\text { Market } \\
\text { Ratio }\end{array}$ & Kontrol & $\begin{array}{l}\text { Rasio ini mencermin kan nilai } \\
\text { suatu perusahaan. Apabila } \\
\text { nilai buku lebih tinggi dari } \\
\text { nilai pasar, maka perusahaan } \\
\text { tersebut undervalue dan } \\
\text { sebaliknya. }\end{array}$ & $\mathrm{BMR}$ & $\begin{array}{l}\text { Rasio } \mathrm{B} / \mathrm{M}=\text { total equity / } \\
\text { market value of equity }\end{array}$ \\
\hline 5 & Tangibility & Kontrol & $\begin{array}{l}\text { Perbandingan plant, property, } \\
\text { and equipment terhadap total } \\
\text { aset perusahaan }\end{array}$ & $\begin{array}{l}\text { TANGIBIL } \\
\text { ITY }\end{array}$ & $\begin{array}{l}\text { Tangibility = plant, } \\
\text { property, and equipment } / \\
\text { total assets }\end{array}$ \\
\hline
\end{tabular}

(Sumber: data olahan peneliti)

\section{Model Penelitian}


Penelitian ini menggunakan metode regresi data panel fixed effects. Program yang digunakan untuk melakukan uji-uji adalah Stata dan SPSS. Berikut merupakan persamaan model regresi yang digunakan dalam penelitian ini:

SMR $_{i, t}=\alpha+\beta_{1}$ DISTRESS $_{i, t}+\beta_{2}$ SIZE $_{i, t}+\beta_{3}$ BMR $_{i, t}+\beta_{4}$ TANGIBILITY $_{i, t}+e_{i, t}$

Imbal Balik Saham $_{i, t}=\alpha+\beta_{1}$ Financial Distress $_{i, t}+\beta_{2}$ Company Size $_{i, t}$

$+\beta_{3}$ Book - to - Market Ratio $_{i, t}+\beta_{4}$ Tangibility $_{i, t}+e_{i, t}$

Keterangan:

SMR $\quad$ : Realized return

DISTRESS : Altman Z-Score

SIZE : Company size

TANGIBILITY: Tangibility

BMR : Rasio book-to-market

\section{Hasil dan Pembahasan}

Statistik Deskriptif

Tabe 2. Output Analis is Deskriptif Statistik

\begin{tabular}{|l|l|r|r|r|r|r|}
\hline Variabel & Satuan & \multicolumn{1}{l|}{ Minimum } & \multicolumn{1}{l|}{ Maksimum } & \multicolumn{1}{l|}{ Mean } & \multicolumn{1}{l|}{ Median } & \multicolumn{1}{l|}{ Standar De viasi } \\
\hline DISTRESS & rasio & $-14,83$ & 66,29 & 5,2719 & 3,6410 & 7,61483 \\
\hline SMR & persen & $-0,79$ & 2,29 & 0,0495 & $-0,0139$ & 0,45403 \\
\hline SIZE & Rupiah & $10,2 \times 10^{8}$ & $440 \times 10^{12}$ & $\begin{array}{r}11,076 \times \\
10^{12}\end{array}$ & $1,445 \times 10^{12}$ & $36,591 \times 10^{12}$ \\
\hline BMR & rasio & $-43,19$ & 27,66 & 1,1901 & 0,8575 & 2,91832 \\
\hline TANGIBILITY & rasio & 0 & 1,25 & 0,3925 & 0,3686 & 0,23807 \\
\hline
\end{tabular}


DISTRESS merupakan variabel independen pada penelitian ini. DISTRESS merupakan rasio yang didapat dari perhitungan Altman Z-Score, yang dimana apabila semakin tinggi angka Altman ZScore atau angka DISTRESS maka semakin kecil financial distress dari perusahaan tersebut. Dari data yang tersedia, didapatkan angka minimum sebesar $-14,83$ per tahun dan angka maksimum sebesar 66,29 per tahun. Rata-rata dari DISTRESS pada penelitian ini adalah 5,2719 per tahun. Sedangkan median dari DISTRESS pada penelitian ini adalah 3,6410 per tahun. Standar deviasi (standard deviation) dari data DISTRESS adalah 7,61483 per tahun. Persebaran data dari DISTRESS dapat dikatakan terpusat dikarenakan persebaran data berada disekitar rata-rata.

SMR merupakan variabel dependen pada penelitian ini. Dari data yang tersedia, didapatkan angka minimum sebesar $-0,79$ per tahun dan angka maksimum sebesar 2,29 per tahun. Rata-rata dari SMR pada penelitian ini adalah 0,0495 per tahun, sedangkan rata-rata SMR dari IHSG (Indeks Harga Saham Gabungan) dalam periode yang sama adalah 0,08898 per tahun. Median dari SMR pada penelitian ini adalah $-0,0139$ per tahun. Standar deviasi dari data SMR adalah 0,45403 per tahun. Persebaran data dari SMR juga dapat dikatakan terpusat dikarenakan persebaran data berada disekitar rata-rata.

Data yang diuji sudah lolos melewati empat tahapan uji asumsi klasik, yaitu uji normalitas, uji heteroskedastisitas, uji autokorelasi, dan uji multikolinearitas. Data yang diuji juga sudah melewati pengujian model estimasi menggunakan uji Chow dan uji Hausman. Hasil dari uji model estimasi tersebut adalah model yang diuji merupakan model fixed effects.

\section{Pengujian Hipotesis}

Tabel 3. Output Uji Regresi Altman Z-Score Dengan Realized Return

\begin{tabular}{|c|c|c|c|c|}
\hline R-s quared & 0,0134 & SMR & Coef. & $P>|t|$ \\
\hline Prob $>$ F & 0,0000 & DISTRESS & 0,0073259 & $0,075^{*}$ \\
\hline & & SIZE & 1,074831 & $0,000 * * *$ \\
\hline & & BMR & $-0,0362497$ & $0,001 * * *$ \\
\hline & & TANGIB ILITY & 0,5787512 & $0,000 * * *$ \\
\hline & & _cons & $-13,26179$ & $0,000 * * *$ \\
\hline
\end{tabular}


Tabel menjelaskan hasil uji regresi Altman Z-Score terhadap realized return ( $\frac{P_{t}-P_{t-1}}{P_{t-1}} \frac{p_{t}-P_{t-1}}{P_{t-1}}$ book-to-market (book value of equity/market value of equity), dan tangibility (plant, property, and equipment/total assets). Data yang digunakan adalah data panel dengan model fixed effects. Model regresi yang digunakan adalah analisis regresi linear berganda.

Untuk uji F statistik, peneliti mendapatkan output Prob>F sebesar 0,0000 dimana memiliki nilai yang lebih kecil daripada 0,05 . Oleh karena itu, keputusannya adalah tolak $\mathrm{H}_{0}$ yang artinya adalah variabel independen (Altman Z-Score) dalam penelitian ini secara serentak memiliki pengaruh terhadap variabel dependen (imbal balik saham/realized stock return) dalam penelitian ini.

Dari hasil pengujian yang dapat dilihat di tabel 4.2, diperoleh hasil bahwa DISTRESS sebagai variabel independen penelitian ini memiliki $\mathrm{P}>|\mathrm{t}|$ sebesar 0,075, sehingga dapat dis impulkan bahwa variabel DISTRESS memiliki pengaruh yang signifikan dengan tingkat kepercayaan $=10 \%$ terhadap variabel dependen penelitian ini (SMR). Sedangkan variabel kontrol penelitian ini (SIZE, BMR dan TANGIBILITY) secara berurutan memiliki nilai $\mathrm{P}>|\mathrm{t}|$ sebesar $0,000,0,001$, dan 0,000 . Hal

ini menandakan bahwa variabel BMR dan SIZE memiliki pengaruh yang signifikan secara parsial $\alpha$

$=1 \%$ terhadap realized stock return (SMR). Berikut persamaan regresi yang digunakan dalam penelitian ini:

$$
\begin{gathered}
S_{M R_{i, t}}=-13,26179+0,0073259 \text { DISTRESS }_{i, t}+1,074831 \text { SIZE }_{i, t} \\
-0,0362497 \text { BMR }_{i, t}+0,57875219 \text { TANGIBILITY }_{i, t}+e_{i, t}
\end{gathered}
$$

Melalui hasil regresi tersebut dapat disimpulkan bahwa variabel DISTRESS memiliki pengaruh negatif terhadap SMR, yang menunjukkan apabila terjadi peningkatan sebesar $1 \%$ terhadap DISTRESS (Altman Z-Score) maka SMR akan mengalami peningkatan sebesar 0,0073259. Hal ini sesuai dengan penemuan Fama dan French (2004) dimana dikatakan bahwa hubungan Altman Z- 
Score berpengaruh positif dengan realized stock return. Hubungan berpengaruh positif berarti semakin tinggi nilai Z-Score suatu perusahaan (semakin menjauhi financial distress), maka perusahaan tersebut akan memberikan realized stock return yang lebih tinggi pula, sesuai dengan hipotesis dari penelitian ini yaitu Altman Z-Score berpengaruh positif terhadap realized stock return.

Dikarenakan model penelitian ini merupakan model fixed effects, maka untuk mengukur uji goodness of fit dapat dengan cara melihat nilai dari $\mathrm{R}^{2}$ overall hasil regresi model ini. Hasil outputnya adalah $\mathrm{R}^{2}$ overall sebesar $1,34 \%$. Dari hasil output tersebut dapat disimpulkan bahwa kemampuan varians variabel independen dalam penelitian ini dalam menjelaskan varians dari variabel terikat yaitu sebesar $1,34 \%$, dimana sebesar 98,66\% lainnya dije laskan oleh faktor la in.

\section{Pengujian Robustness}

Analisis Regresi Perubahan Altman Z-Score Dengan Realized Return

Peneliti melakukan uji robustness untuk mengetahui pengaruh perubahan Altman Z-Score ( $\Delta$ Altman Z-Score sebagai variabel independen) terhadap realized stock return (sebagai variabel dependen). $\Delta$ Altman $\mathrm{Z}$-score adalah perubahan yang terjadi antara nilai Altman $\mathrm{Z}$-score di tahun $\mathrm{t}$

$$
\frac{z_{t}-z_{t-1}}{z_{t-1}} \frac{z_{t}-z_{t-1}}{z_{t-1}}
$$

dikurangi dengan nilai Altman Z-score di t-1 ( $\quad$ ). Tujuan dari uji robustness ini adalah untuk mengetahui pengaruh kenaikan atau penurunan pada Altman Z-score terhadap realized return dalam periode yang sama. Dalam penelitian ini juga terdapat variabel SIZE, BMR, dan TANGIBILITY sebagai variabel kontrol penelitian. Pada pengujian ini, data yang diuji sudah lolos melewati empat tahapan uji asumsi klasik dan uji model estimasi menggunakan uji Chow dan uji Hausman, dan mendapatkan hasil bahwa model ini adalah model fixed effects. Berikut merupakan hipotesis pengujian:

$\mathrm{H}_{0}: \Delta$ Altman Z-Score perusahaan tidak berpengaruh negatif terhadap realized stock return.

$\mathrm{H}_{1}: \Delta$ Altman Z-Score perusahaan berpengaruh negatif terhadap realized stock return.

Peneliti melakukan uji F statistik dan didapatkan output Prob>F sebesar 0,0000 dimana memiliki nilai yang lebih kecil daripada 0,05 . Oleh karena itu, keputusannya adalah tolak $\mathrm{H}_{0}$ yang 
artinya adalah variabel independen ( $\Delta$ Altman Z-Score) secara serentak berpengaruh terhadap variabel dependen dalam penelitian ini.

Tabel 4. Output Uji Regresi Perubahan Altman Z-Score Dengan Realized Return

\begin{tabular}{|l|r|}
\hline R-s quared & 0,0210 \\
\hline Prob $>$ F & 0,0000 \\
\hline
\end{tabular}

\begin{tabular}{|r|r|c|}
\hline SMR & Coef. & P>|t| \\
\hline DISTRESS & 0,0280285 & $0,000^{* * *}$ \\
\hline SIZE & 1,044172 & $0,000^{* * *}$ \\
\hline BMR & $-0,0344301$ & $0,001^{* * *}$ \\
\hline TANGIB ILITY & 0,6693752 & $0,000^{* * *}$ \\
\hline _cons & $-12,87974$ & $0,000^{* * *}$ \\
\hline
\end{tabular}

***signifikansi di level 1\%; **signifikansi di level 5\%; *signifikansi di level 10\%

Tabel menjelaskan hasil uji regresi $\Delta$ Altman Z-Score terhadap realized return ( $\frac{P_{t}-P_{t-1}}{P_{t-1}} \frac{P_{t}-P_{t-1}}{P_{t-1}}$ book-to-market (book value of equity/market value of equity), dan tangibility (plant, property, and equipment/total assets). Data yang digunakan adalah data panel dengan model fixed effects. Model regresi yang digunakan adalah analisis regresi linear berganda.

Dari output regresi yang didapatkan, maka berikut adalah persamaan regresi untuk uji regresi $\Delta$ Altman Z-Score dengan realized stock return untuk uji robustness:

$$
\begin{gathered}
\text { SMR }_{i, t}=-12,87974+0,0280285 \text { DISTRESS }_{i, t}+1,044172 \text { SIZE }_{i, t}-0,0344301 \text { BMR }_{i, t} \\
+0,6693752 \text { TANGBILITY }_{i, t}+e_{i, t}
\end{gathered}
$$

Dari hasil pengujian diatas (tabel 4.3), diperoleh hasil $\Delta$ Altman Z-Score sebagai variabel independen penelitian ini memiliki $\mathrm{P}>|\mathrm{t}|$ sebesar 0,000 , sehingga dapat ditarik kesimpulan bahwa variabel $\Delta$ Altman $Z$-Score berpengaruh signifikan dengan tingkat kepercayaan $1 \%$ terhadap variabel SMR. Sedangkan variabel kontrol penelitian ini (SIZE, BMR, dan TANGIBILITY) secara berurutan memiliki nilai $\mathrm{P}>|\mathrm{t}|$ sebesar $0,000,0,001$ dan 0,000 . Hal ini menandakan bahwa variabel SIZE, BMR, dan TANGIBILITY memiliki pengaruh yang signifikan secara parsial pada level $1 \%$ terhadap realized stock return (SMR). Berdasarkan hasil tersebut dapat disimpulkan bahwa $\mathrm{H}_{0}$ ditolak atau $\Delta$ Altman Z-Score berpengaruh positif signifikan terhadap realized stock return. 
Hasil output dari $\mathrm{R}^{2}$ overall sebesar 2,1\%. Dari hasil tersebut dapat disimpulkan bahwa kemampuan varians variabel independen dalam penelitian ini dalam menjelaskan varians dari variabel terikat yaitu sebesar 2,1\%, dimana sebesar 97,9\% lainnya dijelaskan oleh faktor lain.

Analisis Regresi Altman Z-Score dengan Expected Return

Selanjutnya peneliti melakukan pengujian terhadap pengaruh Altman Z-Score sebagai

$$
\frac{P_{t+1}-P_{t}}{P_{t}} \frac{P_{t+1}-P_{t}}{P_{t}}
$$

variabel independen terhadap expected return, yang didapatkan dari

, sebagai variabel dependen sebagai bentuk uji robustness. Expected return adalah imbal balik dari investasi yang diharapkan akan didapatkan oleh para investor pada periode selanjutnya dalam melakukan investasi (Ross et al., 2015). Perbedaan yang dimiliki oleh expected return dan realized return adalah jika realized return ini sifatnya sudah terjadi, sedangkan expected return adalah kebalikannya yaitu sifatnya belum terjadi. Selain itu, terdapat variabel SIZE, BMR, dan TANGIBILITY sebagai variabel kontrol penelitian. Pada pengujian ini, data yang diuji sudah lolos melewati empat tahapan uji asumsi klasik. Data ini sudah melewati uji model estimasi menggunakan uji Chow dan uji Hausman, dan mendapatkan hasil bahwa model ini adalah model fixed effects. Berikut merupakan hipotesis pengujian:

$\mathrm{H}_{0}$ : Altman Z-Score perusahaan tidak berpengaruh positif terhadap expected return.

$\mathrm{H}_{1}$ : Altman Z-Score perusahaan berpengaruh positif terhadap expected return.

Setelah itu peneliti melakukan uji F statistik dan mendapatkan nilai Prob>F sebesar 0,0000 dimana memiliki nilai yang lebih kecil daripada 0,05 . Oleh karena itu, keputusannya adalah tolak $\mathrm{H}_{0}$ yang artinya adalah variabel independen secara serentak memiliki pengaruh terhadap variabel dependen.

Tabel 5. Output Uji Regresi Altman Z-Score Dengan Expected Return

\begin{tabular}{|c|c|c|c|c|}
\hline R-s quared & 0,0096 & SMR & Coef. & $\mathbf{P}>|\mathbf{t}|$ \\
\hline Prob $>$ F & 0,0000 & DISTRESS & $-0,0082386$ & $0,065^{*}$ \\
\hline & & SIZE & $-1,088674$ & $0,000 * * *$ \\
\hline & & BMR & $-0,0043279$ & 0,706 \\
\hline & & TANGIB ILITY & $-0,3078093$ & $0,053^{*}$ \\
\hline
\end{tabular}


***signifikansi di level 1\%; **signifikansi di level 5\%; *signifikansi di level 10\% Tabel menjelaskan hasil uji regresi Altman Z-Score terhadap expected return ( $\frac{P_{t+1}-P_{t}}{P_{t}} \frac{P_{t+1}-P_{t}}{P_{t}}$ book-to-market (book value of equity/market value of equity), dan tangibility (plant, property, and equipment/total assets). Data yang digunakan adalah data panel dengan model fixed effects. Model regresi yang digunakan adalah analisis regresi linear berganda.

Berikut merupakan persamaan regresi untuk uji regresi Altman Z-Score dengan expected return untuk uji robustness:

$$
\begin{gathered}
\text { SMR }_{i, t}=13,48624-0,0082386 \text { DISTRESS }_{i, t}-1,088674 \text { SIZE }_{i, t}-0,0043279 \text { BMR }_{i, t} \\
-0,3078093 \text { TANGBILITY }_{i, t}+e_{i, t}
\end{gathered}
$$

Dari hasil pengujian yang dapat dilihat di tabel 4.4, diperoleh hasil bahwa DISTRESS sebagai variabel independen penelitian ini memiliki $\mathrm{P}>|\mathrm{t}|$ sebesar 0,000 sehingga dapat disimpulkan bahwa variabel DISTRESS memiliki pengaruh yang signifikan dengan tingkat kepercayaan 5\% terhadap variabel dependen penelitian ini (expected return). Sedangkan variabel kontrol penelitian ini (SIZE dan TANGIBILITY) secara berurutan memiliki nilai $\mathrm{P}>|\mathrm{t}|$ sebesar 0,000 dan 0,053 . Hal ini menandakan bahwa variabel SIZE dan TANGIBILITY memiliki pengaruh yang signifikan terhadap expected return secara parsial pada level 1\% untuk SIZE dan $10 \%$ untuk TANGIBILITY.

Selanjutnya peneliti melihat hasil output dari $\mathrm{R}^{2}$ overall, yaitu sebesar $0,96 \%$. Dari hasil output tersebut dapat dinyatakan bahwa kemampuan varians variabel independen dalam menjelaskan varians dari variabel terikat yaitu sebesar $0,96 \%$, dimana sebesar 99,04\% lainnya dijelaskan oleh faktor lain.

\section{Pembahasan}

Dari hasil uji regresi, didapatkan bahwa dalam penelitian ini kami menolak $\mathrm{H}_{0}$ yang berarti Altman Z-Score perusahaan berpengaruh positif terhadap realized stock return. Ketika suatu perusahaan semakin mengalami financial distress, maka realized stock return yang didapatkan akan 
semakin rendah. Penelitian ini seja lan dengan penelitian sebelumnya yang dilakukan oleh Campbell et al. (2008), Dichev (1998), dan Griffin dan Lemmon (2002) dimana financial distress memiliki pengaruh signifikan negatif terhadap realized stock return. Namun penelitian ini bertentangan dengan penelitian sebelumnya yang dilakukan oleh Chava et al. (2009) dimana dinyatakan bahwa financial distress memiliki hubungan yang positif dengan realized stock return pada penelitian yang menggunakan data-data sebelum tahun 1980, sehingga hasil yang didapatkan adalah hubungan positif yang kuat antara default risk dan expected stock return. Tetapi pada penelitian yang menggunakan data-data setelah tahun 1980, didapatkan hubungan negatif antara default risk dan realized stock return. Sesuai dengan penelitian ex-post yang dilakukan oleh penelitian terdahulu, penelitian ini memiliki hasil bahwa Altman Z-Score memiliki pengaruh yang signifikan positif terhadap realized stock return suatu saham.

Selain itu, peneliti juga melakukan uji robustness terhadap financial distress berupa Altman Z-Score sebagai variabel independen dan expected return sebagai variabel dependen didapatkan hasil bahwa tolak $\mathrm{H}_{0}$, atau Altman Z-Score berpengaruh negatif terhadap expected return. Hasil ini sesuai dengan teori CAPM dimana semakin suatu perusahaan mengalami financial distress maka risiko investasi yang terdapat (leveraged beta) juga akan semakin meningkat sehingga berujung pada peningkatan expected return sesuai dengan Sharpe (1964) dimana semakin besar risiko yang terkandung dalam suatu aset, maka expected return-nya juga akan meningkat.

\section{Kesimpulan}

Penelitian ini meneliti mengenai pengaruh Altman Z-Score terhadap realized stock return. Berdasarkan hasil uji regresi, Altman Z-Score perusahaan berpengaruh positif terhadap realized stock return yang artinya adalah ketika suatu perusahaan semakin mengalami financial distress maka realized stock return yang didapatkan akan semakin rendah. Altman Z-Score memiliki pengaruh yang signifikan dengan tingkat kepercayaan alpha $=5 \%$ terhadap realized stock return. Kemampuan varians Altman Z-Score dalam menjelaskan varians dari realized stock return yaitu sebesar 2,13\%, dimana sebesar 97,87\% lainnya dije laskan oleh faktor lain. Penelitian ini sejalan dengan penelitian 
sebelumnya yang dilakukan oleh Campbell et al. (2008), Dichev (1998), dan Griffin dan Lemmon (2002) dimana financial distress memiliki pengaruh signifikan negatif terhadap realized stock return.

Dalam melakukan penelitian ini, peneliti memiliki tujuan agar penelitian ini memberikan manfaat khususnya bagi para investor, perusahaan, maupun manfaat akademik. Dengan penelitian ini, para investor bisa lebih berhati-hati lagi ketika akan melakukan investasi dengan cara melihat perusahaan yang akan diinvestasikan apakah dalam zona aman, zona abu-abu, atau dalam zona financial distress. Kalau perusahaan yang akan diinvestasikan berada dalam zona aman maka perusahaan baik untuk diinvestasikan. Tetapi jika perusahaan berada dalam zona financial distress, lebih baik para investor tidak berinvestasi di sana dan mencari perusahaan lain yang kondisinya aman karena perusahaan yang sedang mengalami financial distress bisa menyebabkan realized stock return yang didapatkan berkurang atau malah investor bisa mengalami kerugian. Untuk perusahaan (melalui hasil dari perhitungan Altman Z-Score Modifikasi), penelitian ini dapat membantu internal perusahaan agar mengetahui, memantau, dan mempertahankan kondisi keuangan perusahaan khususnya ketika perusahaan sedang berada dalam zona abu-abu dan zona financial distress.

Penelitian ini menggunakan Altman Z Score modifikasi sebagai metode untuk memprediksi financial distress perusahaan. Oleh karena itu, pengaruh dari kondisi kesehatan perusahaan terhadap realized return mengacu pada perhitungan dari rumus-rumus dalam Altman Z Score modifikasi yang mungkin dapat menghasilkan hasil yang berbeda jika menggunakan metode lain dalam memprediksi kondisi distress perusahaan. Beberapa saran yang mungkin dapat dilakukan oleh penelitian selanjutnya adalah menggunakan berbagai macam teori prediksi financial distress selain model Altman Z-Score sebagai perbandingan. 


\section{Daftar Pustaka}

Adnan, H. \& Arisudhana, D. (2012). Analisis Kebangkrutan Model Altman Z-Score dan Springate Pada Perusahaan Industri Property. Jurnal Akuntansi dan Keuangan, 1(1), 89-110.

Altman, E.I. (1968). Financial Ratios, Discriminant Analysis and the Prediction of Corporate Bankruptcy. The Journal of Finance, 23(4), 589-609.

Altman, E.I. (2002). Corporate Distress Prediction Models in a Turbulent Economic and Basel II Environment. Diambil dari: https://core.ac.uk/download/pdf/43021975.pdf

Altman, E.I., Iwanicz-Drozdowska, M., Laitinen, E.K., dan Suvas, A. (2014). Distressed Firm and Bankruptcy Prediction in an International Context: A Review and Empirical Analysis of Altman's Z-Score Model. SSRN Papers, 2014.

Altman, E.I., Iwanicz-Drozdowska, M., Laitinen, E.K., dan Suvas, A. (2015). Financial and Non-Financial Variables as Long-Horizon Pred ictors of Bankruptcy. SSRN Papers, 2015.

Ang, R. (1997). Buku Pintar Pasar Modal Indonesia (The Intelligent Guide to Indonesian Capital Market). Jakarta: Mediasoft Indonesia.

Ardian, A. dan Khoiruddin, M. (2014). Pengaruh Analisis Kebangkrutan Model Altman Terhadap Harga Saham Perusahaan Manufaktur. Jurnal Dinamika Manajemen, 3(1), 1-14.

Campbell, J.Y., Hilscher, J., dan Szilagyi, J. (2008). In Search of Distress Risk. The Journal of Finance, 63(6), 2899-2939.

Chan, K.C. dan Chen, N. (1991). Structural and Return Characteristics of Small and Large Firms. The Journal of Finance, 46(4), 1467-1484.

Chava, S., Livdan, D., dan Purnanandam, A. (2009). Do Shareholder Rights Affect the Cost of Bank Loans?. The Review of Financial Studies, 22(8), 2973-3004.

Darsono dan Ashari. (2005). Pedoman Praktis Memahami Laporan Keuangan. Edisi Kesatu. Yogyakarta: Penerbit ANDI.

Dichev, I.D. (1998). Is the Risk of Bankruptcy a Systematic Risk?. The Journal of Finance, 53(3), 1131-1147.

Fama, E.F. dan French, K.R. (1988). Dividend Yields and Expected Stock Returns. Journal of Financial Economics, 22, 3-25.

Fama, E.F. dan French, K.R. (2004). The Capital Asset Pricing Model: Theory and Evidence. The Journal of Economic Perspectives, 18(3), 25-46.

Fisher, L. (1959). Determinants of Risk Premiums on Corporate Bonds. The Journal of Political Economy, 67(3), 217-237.

Grice, J.S. dan Ingram, R.W. (2001). Tests of the Generalizability of Altman's Bankruptcy Prediction Model. Journal of Business Research, 54, 53-61.

Griffin, J.M. dan Lemmon, M.L. (2002). Book-to-Market Equity, Distress Risk, and Stock Returns. The Journal of Finance, 57(5), 2317-2336.

Gunathilaka, C. (2014). Financial Distress Prediction: A Comparative Study of Solvency Test and Z-Score Models with Reference to Sri Lanka. The IUP Journal of Financial Risk Management, 11(3), 39-51. 
Gunawan, B., Pamungkas, R., dan Susilawati, D. (2017). Perbandingan Prediksi Financial Distress dengan Model Altman, Grover dan Zmije wski. Jurnal Akuntansi dan Investasi, 18(1), 119-127.

Hadi, S. dan Anggraeni, A. (2008). Pemilihan Prediktor Delisting Terbaik (Perbandingan Antara The Zmijewski Model, The Altman Model, dan The Springate Model). Jurnal Akuntansi dan Auditing Indonesia, 12(2), 1-9.

Husein, M.F. dan Pambekti, G.T. (2014). Precision of the models of Altman, Springate, Zmijewski, and Grover for predicting the financial distress. Journal of Economics, Business, and Accountancy Ventura, 17(3), 405-416.

Jensen, M. dan Meckling, W.H. (1976). Theory of the Firm: Managerial Behavior, Agency Costs and Ownership Structure. Journal of Financial Economics, 3(4), 305-360.

Julini, D., Siahaan, Y., Sinaga, M.H., dan Purba, R. (2015). Pengaruh Financial Distress (Altman Z-Score) Terhadap Return Saham Pada Perusahaan Sektor Aneka Industri yang Terdaftar di Bursa Efek Indonesia. Jurnal Ilmiah Sultanist (STIE Sultan Agung), 3(1).

Low, S-W., Nor, F.M., dan Yatim, P. (2001). Predicting Corporate Financial Distress Using The Logit Model: The Case of Malaysia. Asian Academy of Management Journal, 6(1), 49-61.

Malik, U.S., Aftab, M., Noreen, Dr.U. (2013). Distress Risk and Stock Returns in An Emerging Market. Research Journal of Finance and Accounting, 4(17), 81-85.

Meiliawati, A. dan Isharijadi. (2016). Analisis Perbandingan Model Springate dan Altman Z-Score Terhadap Potensi Financial Distress (Studi Kasus Pada Perusahaan Sektor Kosmetik yang Terdaftar di Bursa Efek Indonesia). ASSETS: Jurnal Akuntansi dan Pendidikan, 5(1), 15-24.

Opler, T.C. dan Titman, S. (1994). Financial Distress and Corporate Performance. The Journal of Finance, 49(3), 1015-1040.

Patunrui, K.I.A. dan Yati, S. (2017). Analisis Penilaian Financial Distress Menggunakan Metode Altman (Z Score) Pada Perusahaan Farmasi Yang Terdaftar di Bursa Efek Indonesia Periode 2013-2015. Jurnal Akuntansi, Ekonomi dan Manajemen Bisnis, 5(1), 55-71.

Pindado, J., Rodrigues, L., dan Torre, C.D. (2008). Estimating Financial Distress Likelihood. Journal of Business Research, 61(9), 995-1003.

Ross, S.A., Westerfield, R.W., Jaffe, J.F., dan Roberts, G.S. (2015). Corporate Finance Seventh Edition. New York: McGraw-Hill Education.

Setyawan, F.H., Burhanudin, dan Widayanti, R. (2018). Analisis Financial Distress sebagai Prediktor Delisting PT Berau Coal Energy Tbk. Jurnal Manajemen dan Keuangan, 7(1), 1-9.

Sinarti dan Sembiring, T.M. (2015). Bankruptcy Prediction Analysis of Manufacturing Companies Listed in Indonesia Stock Exchange. International Journal of Economics and Financial Issues, 5 (Special Issue), 354-359.

Springate, G.L.V. (1978). Predicting the Possibility of Failure in Canadian Firm. Unpublished MBA Research Project, Simon Fraser University.

Suharli, M. (2005). Studi Empiris Terhadap Dua Faktor yang Mempengaruhi Return Saham Pada Industri Food \& Beverages di Bursa Efek Jakarta. Jurnal Akuntansi dan Keuangan, 7(2), 99-116.

Thai, S.B., Goh, H.H., HengTeh, B., Wong, J., dan Ong, T.S. (2014). A Revisited of Altman Z Score Model for Companies Listed in Bursa Malaysia. International Journal of Business and Social Science, 5(12), 197 207. 
Whitaker, R.B. (1999). The Early Stages of Financial Distress. Joumal of Economics and Finance, 23(2), 123132.

Widiyawati, A.T., Utomo, S.W., dan Amah, N. (2015). Analisis Ratio Altman Modifikasi Pada Prediksi Kebangkrutan Perusahaan Property dan Real Estate yang Terdaftar di BEI. ASSETS: Jurnal Akuntansi dan Pendidikan, 4(2), 99-111.

Wruck, K. (1990). Financial Distress, Reorganization and Organizational Efficiency. Journal of Financial Economics, 27(2), 419-444.

Zmijewski, M.E. (1984). Methodological Issues Related to the Estimation of Financial Distress Prediction Models. Journal of Accounting Research, 22 (Supplement), 59-82. 